\title{
JOHN LOCKE, CHRISTIAN LIBERTY \\ AND THE PREDiCAMENT OF Liberal TOleration
}

Jakob De Roover, S.N. Balagangadhara

\begin{abstract}
Recently, scholars have disputed whether Locke's political theory should be read as the groundwork of secular liberalism or as a Protestant political theology. Focusing on Locke's mature theory of toleration, the article raises a central question: What if these two readings are compatible? That is, what would be the consequences if Locke's political philosophy has theological foundations, but has also given shape to secular liberalism? Examining Locke's theory in the Letter Concerning Toleration (1689), the article argues that this is indeed the case. The liberal model of toleration is a secularization of the theology of Christian liberty and its division of society into a temporal political kingdom and the spiritual kingdom of Christ. Therefore, when liberal toleration travels beyond the boundaries of the Christian West or when western societies become multicultural, it threatens to lose its intelligibility.
\end{abstract}

KEYWORDS: Locke, toleration, liberalism, secular state, secularization. 
The literature regarding John Locke's political philosophy and its relation to his religious background is so plentiful that one hesitates to contribute another analysis. Yet, a fascinating problem emerges from the current debate. Basically, this debate revolves around the following issue: Was Locke a truly modern thinker whose ideas shaped liberal democracy and the secular state? Or is this classic image mistaken and did Protestant religious doctrine constitute and constrain his thinking? Two camps of Locke interpreters can be opposed along the lines of the answers they give to these questions.

But what if both readings are right? What if Locke's political thought is deeply theological and has also laid the foundations of the liberal secular state? What would be the implications for the status of contemporary liberalism? We will argue that these two interpretations are not incompatible. Focusing on Locke's mature philosophy of toleration in the Letter Concerning Toleration (1689), we will demonstrate that the modern liberal model shares its basic structure with Locke's model of toleration and that this structure derives from the theologies of the Protestant Reformation.

Our thesis is that liberal toleration is a secularized replica of a theological model that divided society into the political kingdom of human authority and the spiritual kingdom of Christian liberty. The liberal model results from an internal Christian dynamic of secularization, which reproduces theological principles in secular guise, instead of emancipating political thought from religious constraints. Consequently, liberal toleration threatens to become unintelligible, when it travels beyond the boundaries of the Christian West or when it has to accommodate communities from other cultures.

\section{LOCKE'S LEGACY AND LIBERAL TOLERATION}

In recent years a key debate has arisen about the philosophical legacy of John Locke. On the one hand, we have authors who assert that he is one of the chief architects of secular liberalism. Hence, his political theory should be interpreted to reveal its relevance to today's political problems. Michael 
Zuckert argues that Locke "is a decidedly modern philosopher" and that liberal democracy is "a system clearly descended from Lockean liberalism." Similarly, many authors endorse the continuing significance of Locke's political thought and locate the prototypical model of liberal toleration in his writings. $^{2}$

On the other hand, we have authors who question the relevance of Locke's political theory to secular liberal democracy. This camp suggests that his thought is deeply rooted in the religious views of his day. In a classical study, John Dunn argues "the intimate dependence of an extremely high proportion of Locke's arguments for their very intelligibility, let alone plausibility, on a series of theological commitments."3 John Marshall and Richard Ashcraft agree that "Locke's theology" was "the central axiom of his political theory." 4

More recently, Jeremy Waldron demonstrates that Locke's conception of equality depends on theological premises. "The theological content cannot simply be bracketed off as a curiosity," he says, for it "shapes and informs the account through and through." Independent of its religious concerns, this conception is "simply unintelligible" and therefore "Lockean equality is not fit to be taught as a secular doctrine, it is a conception of equality that makes no sense except in the light of a particular account of the relation between man and God." ${ }^{5}$ Again we can add several authors who tie Locke to his historical settings or identify Protestant doctrine as the foundation of his political theory. ${ }^{6}$

Generations of eminent scholars have discussed Locke as though his essential ideas are independent of theological premises. Good reasons are available for the belief that Locke's political theory is significant to contemporary liberal democracy: the continuities between his notions of toleration, equality and rights and those which prevail today are striking. His texts have been interpreted to make them intelligible to contemporary minds. Still, the advocates of the thesis that Locke's political thought depends on theological premises make a cogent case. Both Dunn and 
Waldron demonstrate in detail that one cannot grasp many of his claims without a Protestant background.

Why is it so important to know whether or not Lockean toleration depends on theological premises? If this is the case, the conclusion is inescapable that his philosophy is not intelligible when taken as secular political theory. This generates a set of problems with regard to the status of liberal toleration. First, it means that one could make sense of Lockean toleration only within the framework of Christian doctrine. Why, then, has it been understood by so many as religiously neutral?

Second, it could be the case that modern liberal toleration is not related to Locke's Christian thought. Then why have liberal theorists made the mistake of regarding him as their philosophical ancestor, and why do so many feel that our world "is very much a Lockean world"? ${ }^{7}$ Moreover, one should account for the persistent illusion that Lockean toleration shares its basic structure with the modern liberal value. Even if one discards these views as false consciousness, one should explain the nature of the illusion. Galileo told us why the sun seemed to revolve round the earth; equally, the minimal requirement for saving the phenomena is an explanation of the perspective of contemporary liberals.

Third, it could be the case that modern liberal toleration is sustained by the same conceptual scheme as Locke's model. Then the implication would be that-unless given a separate secular foundation — the modern notion also depends on Christian theological premises. In other words, the validity of liberal toleration would be limited to Christian societies. In that case, two consequences are of importance. One: it entails that the political reasoning of contemporary western liberal societies operates within the same religious framework. That is, neither western theories of toleration nor their theorists have become secular. Two: in nonwestern societies, this value fails to make sense and thus it could hardly be a norm for all plural societies. Such a situation jeopardizes the foundations of liberal toleration, since it requires universal validity to make sense as a normative 
political model. In this case, it would be accessible only to Christian believers or those raised in a culture constituted by Christianity.

Waldron notes the problem with regards to the notion of equality: "It may seem to us now that we can make do with a purely secular notion of human equality; but as a matter of ethical history, that notion has been shaped and fashioned on the basis of religion. That is where all the hard work was done." Maybe, he writes, "the notion of humans as one another's equals will begin to fall apart, under pressure, without the presence of the religious conception that shaped it." ${ }^{8}$ Could the same be true for the liberal model of toleration?

\section{The Predicament of Liberal Toleration}

In the Letter Concerning Toleration (1689), Locke intends to "distinguish exactly the business of civil government from that of religion, and to settle the just bonds that lie between the one and the other." Basically, he divides human social life into two spheres: the sphere of civil interests and that of religious pursuits. The civil interests pertain to the liberty and health of the body, and to the possession of outward things such as money, lands and furniture. Human beings are obliged to enter into society to secure these interests. Thus, "the commonwealth" comes into being.

This commonwealth is "a society of men constituted only for the procuring, preserving, and advancing their own civil interests." It has nothing to do with the religious pursuits of its members. Therefore, "the jurisdiction of the magistrate reaches only to these civil concernments" and it "neither can nor ought in any manner to be extended to the soul and its pursuit of salvation." ${ }^{10}$ By "magistrate," Locke understands "the supreme legislative power of any society, not considering the

form of government or number of persons wherein it is placed." 11 His claim is that any supreme legislative power is restricted to the civil interests of its subjects. The realm of religion is exempt from its authority. This is the core of Lockean toleration. 


\section{The Liberal Spheres}

Today, liberal toleration still claims that society consists of two separate spheres: a public political sphere and a private sphere of religion or substantive conceptions of the good. As long as the rule of law is respected, the liberal state ought not to interfere in the religious and moral life of its subjects. ${ }^{12}$ Until recently, the commitment to individual autonomy was the foundation for this principle; now, neutrality towards all substantive conceptions of the good does the job. ${ }^{13}$

Even this new form of political liberalism retains the twofold structure: liberal toleration still depends on dividing human existence into a private personal sphere, in which our comprehensive moral or religious doctrines shape our lives and guide our actions, and a public political sphere, which ought to be governed in terms of a neutral conception of justice. As human beings, we live in two spheres and suffer from a corresponding split of identity: as "citizens" we are subject to state coercion in the public sphere; as "private persons" we are free.

This twofold structure raises a basic problem: how to identify the two spheres? Where to draw the boundary at the normative level, or what is the limit or scope of toleration? ${ }^{14}$ Obviously, immoral behaviors such as murder, torture or child abuse ought not to be tolerated; but there are dubious cases, from pornography to public smoking. What criterion would help determine the scope of the liberal value of toleration? Where does the sphere of liberty end and that of state coercion begin? This has been a central concern of liberal theorists throughout the past few centuries.

The main criterion today is the harm principle: only those practices which do not harm others ought to be tolerated. From Mill's On Liberty (1859) onwards, this has been invoked as the standard in liberal philosophy, politics and jurisprudence. ${ }^{15}$ Given this, the question how we know whether or not our action harms others becomes crucial. If it comprises of direct physical harm only, the principle would not help fix the boundary between the spheres of liberty and coercion. It is difficult to prove that even such flagrant violations of the value of liberty as slavery cause direct physical 
harm as long as the slaves are "treated well." However, once we go beyond physical harm, the obscurity of the harm principle surfaces. ${ }^{16}$ It is often impossible to find out whether an action of ours harms others. For instance, criticisms which hurt a person's ego may be seen as attempts to ruin his psychological health or as efforts to help the person become happier. Hence, if the harm principle embraces mental distress, it becomes indeterminate because no viable criteria exist to determine when one's conduct is psychologically harmful to another.

The contemporary human sciences cannot provide us with a sound foundation for standards like the harm principle. Consequently, the difference between the sphere of personal liberty and that of state coercion becomes subjective, in the sense that it rests on other factual premises. That is, depending upon one's metaphysical premises, one distinguishes between the two spheres differently. At the normative level, it becomes impossible to separate them.

\section{The Puzzle of the Two Spheres}

What then is the status of the twofold structure of liberal toleration? How could we clarify the distinction between the public sphere of political coercion and the private sphere of religious freedom? If we want to explain the value of toleration to the non-modern, non-liberal or the nonwestern world, we cannot assume that human lives have such a "natural" dual structure. The challenge is to provide a criterion to identify either of the two spheres at the empirical level. How to do so? The public or political sphere appears to refer to the domain of the state and its legal apparatus, whereas the private sphere of religion consists of what is left over. But this does not allow us to identify these spheres, since any domain of human existence is subject to state laws at some point, while free from them at other points.

Many theorists argue that "the distinction between the public and the private...is a slippery one, incapable of being established in a way that accords either with an adequate empirical description of the major institutions of modern society or with satisfactory normative justifications" and conclude 
that it concerns "a shifting and uncertain boundary." ${ }^{17}$ Such remarks could be indefinitely multiplied. ${ }^{18}$ Similar points are made about the division between the religious and the political: in spite of the plethora of definitions of "religion," we do not possess a sound theoretical criterion to identify the realm of religion or distinguish it from the political realm. ${ }^{19}$

To say that the boundary is "constantly being renegotiated" or is "an essentially contested distinction" evades the issue. The difficulty does not revolve around where the line is drawn between the two spheres. Consider the case of a country and its borders. The renegotiation of the borders does not make the country unidentifiable. Rather, the problem is to describe what lies within the borders. Even if its borders change, France remains recognizable. One can still identify it as a distinct nation-state. In the same way, the puzzle of the two spheres is not about the precise location of the boundaries. To make sense of the distinction, one should be able to recognize or identify at least one of the two spheres. Either one possesses a criterion to identify the private sphere of religious liberty and distinguish it from its public political counterpart, or vice versa. Such a criterion would describe the properties of one of the two spheres. Surely one needs such a criterion, when one's normative political theory divides society into two separate realms. ${ }^{20}$

\section{The Lockean Spheres}

If Lockean toleration requires such a twofold division of society, then it may also confront a similar difficulty. Admittedly, Locke says, "a good life" involves religion and piety, but it "concerns also the civil government." ${ }^{21}$ Moral actions fall under the jurisdictions of both magistrate and conscience. This creates the danger of one encroaching upon the other. Therefore, it is of vital import to distinguish between these two realms. First, Locke characterizes the realm of religion:

Every man has an immortal soul, capable of eternal happiness or misery; whose happiness depending upon his believing and doing those things in life, which are necessary to the obtaining of God's favour, and are prescribed by God to that end: it follows from thence, first, 
that the observance of these things is the highest obligation that lies upon mankind, and that our utmost care, application, and diligence ought to be exercised in the search and performance of them; because there is nothing in this world that is of any consideration in comparison with eternity. Secondly, that seeing one man does not violate the right of another, by his erroneous opinions, and undue manner of worship, nor is his perdition any prejudice to another man's affairs; therefore the care of each man's salvation belongs only to himself. ${ }^{22}$

The realm of religion is that of the immortal souls of all human beings, who strive for salvation by worshipping God. It is the other eternal world, whose obligations override everything else from this world. At most, human beings can try to persuade each other of the truth of a particular doctrine or form of worship, but "all force and compulsion are to be forborn" in this realm. ${ }^{23}$ In the realm of civil interests, however, force and compulsion are necessary:

But besides their souls, which are immortal, men have also their temporal lives here upon earth; the state whereof being frail and fleeting, and the duration uncertain, they have need of several outward conveniencies to the support thereof, which are to be procured by pains and industry... But the pravity of mankind being such, that they had rather injuriously prey upon the fruits of other men's labours than take pains to provide for themselves; the necessity of preserving men in the possession of what honest industry has already acquired, and also of preserving their liberty and strength, whereby they may acquire what they farther want, obliges men to enter into society with one another; that by mutual assistance and joint force, they may secure unto each other their properties, in the things that contribute to the comfort and happiness of this life... ${ }^{24}$

This realm corresponds to the temporal lives of human beings on earth, where they need material goods to survive. They enter into civil society to protect these interests. This happens through the 
creation of an "original compact," in which they agree to entrust the power to protect their temporal goods to the civil authority.

The reason for entering into civil society also determines the boundaries of its legislative power: it ought to be directed only towards "the temporal good and outward prosperity of the society," and "it is also evident what liberty remains to men in reference to their eternal salvation, and that is, that every one should do what he in his conscience is persuaded to be acceptable to the Almighty, on whose good pleasure and acceptance depends his eternal happiness." ${ }^{25}$ Locke’s text leaves no doubt: religion is the spiritual realm of the human soul, which is free from human authority and laws; the commonwealth is the temporal realm of the human body subject to the legislative power of the magistrate.

"There is a twofold society," Locke had stated in an earlier note, "of which almost all men in the world are members, and that from the twofold concernment they have to attain a twofold happiness; viz. that of this world and that of the other: and hence there arises these two following societies, viz. religious and civil." ${ }^{26}$ On the basis of this distinction, Locke explained the view of toleration which he would develop more fully in his Essay on Toleration and in the letters concerning

toleration. ${ }^{27}$ This theological division between civil and religious society, between this world and the other, between the body and the soul, is necessary to make his theory intelligible.

\section{CHRISTIAN LIBERTY AND ITs Two KINGDOMS}

The Letter Concerning Toleration was not the first text on the subject in the seventeenth-century England. The question of toleration had brought about heated disputes between the Anglicans, Puritans and radical Protestants. ${ }^{28}$ There is no need to go into the details of these debates; a brief sketch of their shared framework will do for us.

The Reformation transformed the earlier Christian relationship between the spiritual and the temporal worlds dramatically. Whereas the earlier medieval distinction was between the clergy and 
the laity, this hierarchical division was now rejected. Luther argued from the 1520s that no spiritual estate of priests could exist as opposed to a temporal estate of laymen. All human beings lived in these two worlds simultaneously. All believers were priests and all souls ought to be free so that they might be "regenerated" by the Holy Spirit. ${ }^{29}$ This was the core idea of "Christian liberty." As sinners, we fail to submit ourselves to the will of God. Therefore, the divine will has to act in each one of us and instill true faith in our hearts. ${ }^{30}$

The Protestant notion of Christian liberty implied that all human laws in the spiritual realm were violations of true religion. The canon law of the Roman Church, John Calvin asserted in his Institutes (1559), had denied this liberty and invaded the Kingdom of Christ, and "thus the freedom given by him to the conscience of the believers is utterly oppressed and cast down." The main problem was that human laws were prescribed as though they were spiritual, "enjoining things necessary to salvation," but "our consciences do not have to do with men but with God alone. This is the purpose of that common distinction between the earthly forum and the forum of conscience." If "God is the sole lawgiver," Calvin concluded, "men are not permitted to usurp this honor." 31

This notion gave rise to a political theology which became central to the early modern notion of toleration, vir: the theory of the two kingdoms. In Calvin's words, “there is a twofold government in man: one aspect is spiritual, whereby the conscience is instructed in piety and in reverencing God; the second is political, whereby man is educated for the duties of humanity and citizenship that must be maintained among men." These are the "spiritual" and "temporal" jurisdictions, he added, "by which is meant that the former sort of government pertains to the life of the soul, while the latter has to do with the concerns of the present life_- not only with food and clothing but with laying down laws whereby a man may live his life among other men holily, honorably, and temperately." The first is the spiritual kingdom, which resides in the inner mind, while the second is the political kingdom, which "regulates only outward behavior." 32 Luther emphasized this point in his tract on 
Temporal Government (1523): "The temporal government has laws which extend no further than to life and property and external affairs on earth, for God cannot and will not permit anyone but himself to rule over the soul." 33

The theology of the two kingdoms claimed the following: (a) all human beings live in two spheres - the spiritual kingdom of Christ and the political kingdom of human authority; (b) in the spiritual sphere, they strive for the salvation of their souls, which is purely an individual affair over which God alone has authority; (c) in the temporal sphere, they are sinful bodies who pursue the preservation of their earthly interests and must always obey the laws of the secular powers. The two kingdoms should never be mixed up— the state should never prescribe laws in the spiritual realm— for this was equivalent to ranking human authority above that of God. Although it would take time before Protestants also practiced this theology, it provided the framework within which debates on toleration took place.

Turning back to Locke's mature theory of toleration, his basic conceptual scheme is virtually identical to that of the theology of Christian liberty. Luther and Calvin claimed that God's promise of grace in Christ makes religion free from all human laws. But, they added, this freedom was confined to the spiritual realm of the soul, which could be regenerated by the Holy Spirit. The carnal body would always be sinful and therefore it ought to be subject to the laws of the temporal power. God had dispensed a fraction of His sovereignty to the princes so that they may restrain human depravity. Neither the prince nor the priest, however, had the authority to infringe upon the relationship between God and each soul.

In Locke's theory, the sovereignty of the civil government is justified in terms of a social contract, but its justification of political coercion is very similar. As he puts it, "the pravity of mankind being such, that they had rather injuriously prey upon the fruits of other men's labours than take pains to provide for themselves," men are obliged to enter into society and bestow a 
coercive power on the civil government. ${ }^{34}$ This is another way of saying that carnal man is a sinful being, who needs to be restrained through coercive laws. The soul is liberated from human laws through the liberty and power of the Christian faith. And so it is in Locke's theory of toleration: the temporal life of our depraved bodies in civil society is subject to the sovereign of the original compact; the religious life of our souls becomes a sovereign sphere in and of itself.

Our hypothesis is the following: the model of liberal toleration of Locke and later liberal thinkers is a secularized replica of the theological model of Christian liberty and its two kingdoms. The model has been secularized in the sense that certain theological premises and details have been discarded, while retaining its basic conceptual structure. In Locke's Letter, this theology is still explicit. Many have shown how most of his arguments for toleration are theological in nature. ${ }^{35}$ Locke's conception of the church as "a voluntary society of men, joining themselves together to their own accord, in order to the public worshipping of God" also presupposes the ultimate autonomy of the believer's soul in his relation to God. ${ }^{36}$

The theological framework in which it is cast precludes this model of toleration from including those religions which do not live up to its separation of civil and religious society. As Locke wrote: "That church can have no right to be tolerated by the magistrate, which is constituted upon such a bottom, that all those who enter into it, do thereby, ipso facto, deliver themselves up to the protection and service of another prince." ${ }^{37}$ This excluded Catholicism as long as it demanded obedience to the papal hierarchy. The model also ruled out opinions that were thought to destroy civil society, such as atheism. This was the case, because the limits of Locke's toleration were fixed by the theology of Christian liberty and its view of true religion.

\section{RETHINKING LOCKEAN TOLERATION}

Can Locke's model of toleration liberate itself from this theological framework? In a recent article, Alex Tuckness seeks to demonstrate the significance of Locke to contemporary liberalism by 
recuperating certain elements from the letters on toleration: (a) the argument that one ought not to suppress any religion, since all human beings are fallible in matters of religious truth and (b) the principle that all religions ought to be tolerated as long as they do not harm human beings or civil society in general. ${ }^{38}$

How does Locke's theory resolve the predicament of moral and religious diversity in society? Imagine a situation where two civil magistrates believe that they each have the true religion. Could they, as magistrates, act upon this belief? According to Tuckness, Locke suggests that in such cases one must move to the perspective of a legislator who formulates a principle that will guide both magistrates. In Locke's account, the legislator is God, who would never allow the magistrates to impose their religion on the subjects, for He takes into account the fallibility of the agents who will carry out His instructions. This is what Tuckness calls "the legislative point of view." ${ }^{39}$ In his interpretation of Locke, this is taken as a reasonable secular principle for legislators, since "a magistrate trying to decide whether or not to suppress a religion he believes dangerous would have to ask not only whether suppressing the religion would promote the public good but also whether it would promote the public good for other magistrates to act on the same principle."40

Tuckness argues this principle is worth saving from Locke's argument. He separates four different levels. At the first level, there are Locke's theological foundations:

At level two there is the general principle...that our political principles be ones that we would want others who are fallible and partial like ourselves to interpret and apply. The specific principle (level three)... was that the magistrate should not tolerate those beliefs that would be incompatible with the possibility of civil society if widely held. ${ }^{41}$

At the fourth level, Locke argued against the toleration of certain variants of Catholicism and atheism. Tuckness discards both Locke's level-four argument and his level-one theological commitments, while retaining the general and the specific principle. 
How are these elements from Locke's theory significant to contemporary political theory? First, "Locke's level-two argument...gives us a more reliable way of taking human fallibility into account." Second, the specific principle "to suppress only those beliefs that would make civil society impossible if widely held," is widely accepted. Third, one of the strengths of this interpretation is that the general principle constrains the specific principle. Tuckness takes the example of the expression of racist ideas in society. These certainly cause harm, yet we have doubts about the refusal to tolerate such ideas: "Given the tremendous harm that the expression of racist ideas can cause, why should such speech be protected?" The general principle gives us a good reason to do so: "We tolerate racist ideas because the alternative would give too much power to fallible and partial human beings, not because racist ideas have intrinsic value." ${ }^{42}$ In this manner, levels two and three of Locke's theory allow us to address certain problems of secular political theory.

Let us look at his suggestions in the following light: Is it possible to divorce the second level arguments of Locke from his theological arguments? As Tuckness himself claims, the level two arguments are derived from theological arguments. ${ }^{43}$ Thus, to what extent is the level two principle independent of Christian theology? First of all, it requires noting that no human being, ever, could really assume a "legislative point of view," namely, the perspective of the Lockean Legislator, who is none other than God. A magistrate could assume such a point of view only if he was infallible and complete, the way God is. If a person is capable of formulating a principle assuming a legislative point of view, it is not obvious why the same person is denied the possibility of also giving an interpretation from the same point of view. How is it possible to suggest that one's political principle does not reflect one's partiality and fallibility, whereas one's interpretation and application of the same principle does? The very possibility of talking about fallible and partial magistrates depends upon the human impossibility of assuming the "legislative point of view." In this sense, this suggestion transforms us into strange creatures possessing impossible properties: the ability to 
formulate "impartial" and "infallible" principles, while lacking the ability to provide anything but partial and fallible interpretations. ${ }^{44}$

Given furthermore that the predicament of fallibility is shared by all human beings, the only political principles that a magistrate can make his own are those that are formulated by a non-human being, who knows what an impartial and infallible interpretation is. Such a being is God in Locke. In other words, the requirement of consistency is that Locke's general principle cannot be divorced from its theological background.

Is it not possible to suggest that we can formulate principles without knowing all their possible consequences? (Such a consequence set would be the set of all possible and permissible interpretations.) This defense has no teeth. On their own, principles have no consequences; only the theories in which they are embedded do. If one and the same statement (after all, a principle is also a linguistic entity) has a different consequence in different theories, surely, one cannot argue that each of them is a consequence of that statement. Minimally, the consequences depend on other premises and the used rules of inference. In this sense, this avenue is completely closed to Tuckness. Here, we can see the weakness of his proposal even more clearly: no principle, on its own, has any interpretation. Principles which are embedded in theories are required to speak about their possible interpretations. One cannot simply extract some principle from Locke without extracting other claims, which enable a Lockean consequence.

Consider now the specific principle: only those beliefs and practices which are fundamentally harmful to civil society ought to be suppressed. Tuckness admits that this principle is problematic, since "there is disagreement about which beliefs, if generalized, would make civil society impossible." Still, he concludes, "the gap between Locke's position and the alternatives is not so great as to render his specific principle a mere historical curiosity." 45 
Again, the formulation is inadmissible, if proposed as a secular translation. No human being can know (infallibly) which principles, if widely held, would make civil society impossible. One can only entertain partial and fallible beliefs about the relationship between beliefs and the possibility of civil society. Because these vary in time and place, such beliefs create difficulties.

To illustrate this difficulty, take the historical example of Ancient Rome. The pagan citizens of Rome, including their magistrates, believed that some of the calamities that befell Rome had to do with the fact that the Christians and Jews did not worship the deities of the Roman Empire. The latter, in their turn, refused to worship the Roman deities, because the biblical God forbade idolatry and the worship of demons. According to the pagans, this belief, if widely held and practiced, would lead to the destruction of Roman society. Taking Tuckness' specific principle, it follows logically that coercing the Christians and the Jews to worship the Roman deities would express Lockean toleration in this context. However, it would also violate Locke's principles, because the Roman magistrates would impose their own fallible beliefs and interfere with the religious beliefs and practices of the Jews and Christians. So, one and the same act of coercing the Jews and the Christians into worshipping the Roman deities would express both toleration and intolerance. ${ }^{46}$

The only route open is to bring infallibility back into the picture: one has to introduce a set of absolute principles authored by some being that is neither fallible nor partial. One has to also postulate that, no matter whether the interpretation is fallible and partial, violating such principles (objectively and independent of human beliefs) would make civil society impossible. Otherwise, inconsistency threatens: as in the case of Ancient Rome, the magistrate has to judge what religion is, what is harmful to civil society, and which practices ought to be tolerated and which not. In short, each magistrate judges, according to his beliefs, what is and is not "toleration." This is not liberal toleration, but tyranny at its worst. 
There is, even here, logic to madness: attributing the properties of God to humanity leads to tyranny by human beings. Believers do not see in God's sovereignty any trace of tyranny or arbitrary rule, because God is both perfectly consistent and perfectly good. However, one cannot transfer this sovereignty to humanity without inviting tyranny, because of the human creature's fallibility and partiality. In this sense, one is faced with the choice: either reintroduce Christian theology or defend tyranny in the name of toleration. In the first case, the Lockean principles are infallible and impartial, because they are revealed by God. But then, the same God has also infallibly revealed what religion is: it concerns spiritual worship, the soul and the conscience alone, and has nothing to do with civil society. This is what the theology of Christian liberty tells us. In short, one cannot simply get rid of Locke's Protestant framework as though it is extra conceptual baggage; it is not.

\section{THE MODEL OF AMERICAN LIBERALISM}

Locke's model of toleration proved a perfect fit for many American states of the eighteenth century. Eventually, it would be translated into the constitutional principle of separation of church and state. Did this principle emancipate liberal toleration from its theological framework? This seems to be the case: God is not even mentioned in the American Constitution.

Historically, the principle of separation was defended by two distinct groups. There were "liberal Protestants" like the Baptists, Quakers and others, and "Enlightenment rationalists" or "secularists" such as Thomas Jefferson and James Madison.

The first group invoked the theological framework of Christian liberty and the arguments from seventeenth-century England in order to advocate liberty of conscience. ${ }^{47}$ When the colonies gained independence in 1776, this framework was translated into a legal and political form. The diversity of denominations in most states guaranteed that the right to worship God according to the dictates of one's conscience would be protected by law. ${ }^{48}$ The different legal documents of the eighteenthcentury American states declared that all would be free to fulfill "the duty which we owe to our 
Creator." ${ }^{49}$ These legal formulas were meaningful, because they could presuppose a common theological understanding of what religion is: namely, the duty and right of all human beings to worship their Creator in such manner as they see fit.

However, it is argued that the separation of church and state was founded in religious premises for this group, while it was a secular principle for the Enlightenment freethinkers. ${ }^{50}$ Did the theological framework really disappear in the political thought of American founders like Thomas Jefferson?

It is difficult to give a straightforward answer to this question, because Jefferson did not develop any clear theory. His thoughts on this matter must be reconstructed from a few paragraphs in his letters, legal texts and other writings. Nonetheless, these statements have shaped the American tradition of separation of church and state. Take the famous Act for Establishing Religious Freedom (1786). One cannot overstate its import, claims Susan Jacoby, "for, much to the dismay of religious conservatives, it would become the template for the secularist provisions of the federal Constitution." 51

At first sight, there is no conceptual break with the earlier theological model. In fact, the justification of the Virginia Act reads like a digest of Christian liberty. It talks about "the Almighty God who hath created the mind free" and emphasizes that temporal punishments related to religion are "a departure from the plan of the Holy Author of our religion." 52 These are obvious theological statements: it is God's will for human beings to be free in matters of religion. Naturally, one could argue that the claims about God are "a rhetorical flourish, not a legal requirement." " Can the theology in Jefferson's advocacy of religious liberty indeed be dismissed as rhetoric?

From the Virginia Act, it is but a small step to the famous establishment clause in the first article of the First Ten Amendments to the Constitution of December 15, 1791. Jefferson's understanding 
of the establishment clause as "a wall of separation" appeared in a letter to the Danbury Baptist Association (1 January 1802):

Believing with you that religion is a matter which lies solely between man and his God, that he owes account to none other for his faith or his worship, that the legislative powers of government reach actions only, and not opinions, I contemplate with sovereign reverence that act of the whole American people which declared that their legislature should "make no law respecting an establishment of religion, or prohibiting the free exercise thereof," thus building a wall of separation between Church and State. ${ }^{54}$

The metaphor of the wall of separation has achieved an "almost canonical status" in the interpretation of the establishment clause of the Constitution and the American judiciary has made it "a virtual rule of constitutional law." 55

Strikingly, two out of three reasons which Jefferson gives for the separation of church and state are explicit theological doctrines. Religion is a matter between each human individual and his or her God and no other human being ought to intrude upon this relationship. In his Notes on the State of Virginia (1787), Jefferson had said that many still believe that the operations of the mind are subject to legal coercion, but rulers can only govern the domains which we submit to their power: "The rights of conscience we never submitted, we could not submit. We are answerable for them to our God." 56 These were the principles of the theology of the two kingdoms.

Nevertheless, some of Jefferson's arguments appear secular at first sight. What remains of his case, if we discard all explicit theological elements? If we take away God from his account in the Virginia bill and his Notes, here is what remains: (a) Our civil rights are distinct and independent of our religious opinions. (b) Religious opinions are harmless to civil society and therefore civil government ought to leave these free. As Jefferson put it in the Notes: "The legitimate powers of government extend to such acts only as are injurious to others. But it does me no injury for my 
neighbour to say there are twenty gods, or no god. It neither picks my pocket nor breaks my leg." (c) Legislators are fallible men and therefore ought not to rule over the faith of others: "Subject opinion to coercion: whom will you make your inquisitors? Fallible men; men governed by bad passions, by private as well as public reasons." ${ }^{57}$

The first principle fails to provide a secular foundation for the separation of civil and religious society, since it presupposes the same. When one does not agree that religion ought to be separated from civil political society, one also fails to see why our civil rights should be independent of our religious opinions. Only the harm principle and the fallibility principle remain. Remarkably, these are the two principles that Tuckness also extracts from Locke's theory.

We can again see the problem in these two principles, if we apply them to the plural societies of the early modern West, including Jefferson's America. Many churches, magistrates and citizens of these societies were convinced that God would inflict catastrophes on a Christian society, if it allowed heresy, blasphemy, irreligion, or false religion. Other magistrates and citizens-radical Protestants and Deists, in particular-insisted that God would never interfere in civil society in this way.

If any magistrate were to implement the fallibility principle and the harm principle in such societies, he would face a conflict. According to the fallibility principle, he would have to acknowledge that both opinions about God and His wrath were held by fallible humans and should not be imposed on others. The harm principle, however, would lead to incompatible results accordingly as the magistrate held one of the two beliefs. If he believed that God would never interfere in earthly life, he could indeed insist that "it does me no injury for my neighbour to say there are twenty gods, or no god." But if he held the other belief in God's wrath, he would consider civil society to be severely affected by the same toleration. The two principles would conflict: in 
order that the harm principle may lead us to toleration, we should impose our belief about God's non-interference in temporal society on all citizens.

In Jefferson's philosophy of toleration, as in Locke's, this inconsistency does not arise, because the principles are based in the belief that religion is a strictly an individual matter between each human being and God. Hence, such claims as "Almighty God hath created the mind free," that "religion is a matter which lies solely between man and his God," and that we are answerable to our God alone for the rights of conscience are not rhetorical flourishes. They provide the theological framework necessary to make sense of Jefferson's vindication of the separation between the church and the state. This framework can either be explicitly present; or it can shift to the background, as it has in the American common sense.

The conceptual problems arise precisely because one tries to extract two principles of the Protestant framework of Christian liberty, without heeding its theological constraints. The normative view of this framework claims that religion is the relation between an individual believer and God, which does not affect civil society in any way. As long as one holds this premise, the problem does not come into being. In Locke's theory, both the consideration of human fallibility and the principle that all religions ought to be tolerated as long as they do not harm civil society are limited by this theological view of religion. One thing is certain: God's wrath will not destroy a society that allows heresy and idolatry, since religion is the spiritual relationship between God and each human soul, which is distinct and independent of the bodily life in temporal societies. In other words, Lockean toleration is consistent within this theological framework. When one secularizes its principles into independent normative tenets, new conceptual problems arise, which were not present in the original. 


\section{The Predicament of Secularized Theology}

A common view says that "John Locke is the essential philosopher-advocate of liberal freedom and government - and of the state of mind designed to protect and spread them." 58 Why have generations of thinkers read Locke as though he was the father of secular liberal democracy? Where do the structural similarities between his conception of toleration and the modern liberal one come from?

The following hypothesis addresses these questions: the modern liberal conception of toleration has emerged from the secularization of the theology of Christian liberty and its separation of the two kingdoms. We read Locke as though his Christianity is but a religious layer that provided color to the essentially liberal structure of his political thought. He is the father of modern liberalism first and a Protestant believer second. We are wrong. His political thought is Christian to the core. We are right to identify the basic scheme of liberal toleration in Locke's Letter. But this does not demonstrate that his thought is secular political theory. Rather, it indicates that the modern liberal thought continues to be religious, since it conceals an essentially theological structure in secular garb.

The steps from Locke to Jefferson and beyond are not those of a rational Enlightenment, which extends its secular values to humanity, but those of an internal religious dynamic of secularization, which spreads Christian principles in a secular guise. The liberal model of toleration is constrained by the conceptual schemes it has inherited from its theological background. In this internal secularization of the Protestant religion, such a set of conceptual schemes is detached from the theological framework that made them intelligible and significant. These become the building blocks of normative political thought.

We can illustrate this process of secularization in terms of the puzzle of the two spheres. In the theology of Christian liberty, the division of human society into a sphere of political coercion and one of religious liberty does not cause any conceptual problems. It is founded in the Christian 
anthropology: each individual human being consists of a soul and a body; and human life and society consist of spiritual and temporal realms accordingly. Human authorities can rule over the latter alone, for God is the only spiritual Lord. In Locke's defense of toleration in the Letter, these theological elements are still explicitly present. They are necessary to make sense of his account, since it is simply impossible to identify any of the two domains without reference to these background beliefs.

Once we take the step to the modern liberal thought on toleration, however, the division of human society into a political and religious realm becomes a pre-theoretical starting-point. No need is felt to clarify it; it is simply presupposed. The consequence is opacity: one does not know how to identify either the private domain of religious liberty or its public counterpart. The problem emerges because the liberal notion of toleration is built on theological schemes, which have been rid of their "salient" Christian features. The puzzle of the two spheres is one of the conceptual problems that are bound to materialize when this theological background is ignored.

This puzzle becomes acute when liberal principles travel to societies that do not share the commonsense background of the West. Lacking both the explicit Christian theology and its secularized counterpart, the intellectuals of non-western societies are bound to tie themselves in knots while seeking to defend liberal toleration. As an illustration, consider the debates about the Uniform Civil Code in India.

From the 1930s until today, political representatives in India, who agreed upon the tenets of a liberal secular state, have disagreed vehemently about the implications of having such a state. According to some Muslim representatives, the principles of state neutrality and religious liberty entail that Muslim communities ought to be free to live according to Islamic personal law. Ordained by God, this personal law is part of their religion, they argue. Since a liberal secular state ought to 
leave the citizens free to live according to their religion, it should not impose a Uniform Civil Code on Muslim communities. ${ }^{59}$

The opponents of this position argue that religion does not encompass personal law. Therefore, the implementation of a secular liberal state entails that a Uniform Civil Code ought to be imposed on all citizens, irrespective of religious affiliation. ${ }^{60}$ This dispute is not about the validity of the principles of liberal toleration, but about their meaning given a variety of conflicting conceptions of religion. ${ }^{61}$ It is a factual dispute about the nature and identity of religion: What characterizes the religious realm as opposed to other realms of society? Do such things as inheritance law, diet, mode of dress, etc. belong to the realm of religion or not?

In the absence of a theoretical framework that conceptualizes religion and distinguishes its realm from the public realm, such debates threaten to become as interminable as disputes about taste. One lacks cognitive grounds to settle the issue. Either one takes recourse to common sense to do so or one invokes a stipulative definition. Here, no shared common sense is available; hence, the endless disputes that invoke conflicting definitions of "religion."

To refer to the "essentially contested" character of notions like religion is to make it seem as though such disputes reflect a normal state of affairs. But the problem remains. In the seventeenthcentury debates about toleration among Christians, there was agreement on the principles of Christian liberty. However, the exact boundaries of the realm of religion and the implications of these normative principles were contested. Some claimed that religious liberty referred only to freedom to hold religious beliefs; others argued that it also encompassed the freedom to express and practice these beliefs. ${ }^{62}$ These debates took place against the background of a shared framework about the nature and characteristics of religion: the soul worshipped God; the eternal spiritual world was described in the Scripture. Such a minimal consensus, necessary to render the different positions intelligible, is precisely what is missing in the contemporary debates. 
This gives us a further insight into the relationship between the dynamic of secularization and liberal political theory. It is as though the Christian theological framework is retained, while its propositional content is almost rejected. If we see such a framework as a semantic structure containing both constants and variables (where the different interpretations of the variables provide us with different Christian theologies), and where the domain and range of the variables are constrained by the nature of the constants, then secularization implies this: the framework, together with its constants, fades into the background; yet, it continues to constrain the range and domain of the variables. The principles of the theology of Christian liberty are upheld by liberal toleration; the theological framework that gave such principles a body and content in terms of a conception of the world has faded into the background.

The secularization of the theology of Christian liberty also produces a series of normative principles as axioms of liberal political thought. Good examples are the right to religious liberty and the separation of state and religion. Both principles make perfect sense when embedded in Protestant doctrines, as they are in the writings of Locke. The norm that each human being ought to be free in the spiritual realm is sustained by a set of background beliefs about true faith as the work of God in the human soul. The necessity of the separation of state and religion becomes equally obvious when this understanding of religion is present in the background. To subject the domain of religion to the authority of the state is equivalent to subjecting God's Will to human laws.

These norms had such an obvious character to Locke, because they were "willed by God." When extracted from this theological framework, these principles seem to retain their self-evident character: all reasonable thinking on the problem of diversity in a democratic society should take the right to religious liberty and the separation of church and state as its starting points. ${ }^{63}$ Yet political theorists feel the need to provide normative justifications for these principles of religious liberty. 
This is a consequence of the secularization of norms based in a specific religious account of religion and its liberty. One can no longer invoke the theological conception of human existence to justify the principles of liberal toleration. One feels the need to provide a secular justification; but one lacks the conceptual resources to do so. That is, no scientific theory is available today which identifies the realm of religion across different cultures and societies, and which explains what it means for religious worship to be free and why a human society needs freedom of religion in order to flourish.

\section{CONCLUSION}

We believe that all theories of liberal toleration presuppose the truth of a Christian anthropology in one way or another. Their division of society into the two spheres and their claims about the freedom of religion depend on this background framework. Maximally, this theological anthropology makes sense also to Jews and Muslims, but it does not do so to others.

Naturally, in itself, the fact that some sentence or principle_-say, "Man is born free, and yet everywhere he is in chains"fast distinction between religious claims (or theories) and secular ones. No semantic or epistemic property transforms some isolated statement into a religious or secular statement. However, our point is that a sentence like Rousseau's cannot be intelligible or profound without a background set of beliefs. It is such a background that lends intelligibility, depth and poignancy to the formulation.

Even if such sentences or principles have a Christian origin, could one not provide them with a secular foundation? Only to those to whom such principles already have depth and poignancy, would it even occur to want to provide a secular foundation. From the perspective of Indian culture, for instance, the claim that "Man is born free, and yet everywhere he is in chains" is neither deep nor poignant, but false and trivial. In this sense, one can bring out the presupposition in the above question with a counter-question: why bother providing a secular foundation to a religious principle 
at all? The only possible answer lies in the value and importance of that principle. But, on its own, the principle is opaque and unintelligible. Its value and significance are derived from what surrounds it: other beliefs. The principle is part of a religious Gestalt and what makes it appear valuable lies in it being a part of that Gestalt.

To appreciate the point better, consider the following example. Many Hindus would find the statement "tat tvam asi" ("thou art that") a very profound, poignant and deeply moving truth. The idea lacks intelligibility, let alone truth, to someone who does not accept a set of other beliefs required to see its truth, simplicity or beauty. What would we make of an Indian claiming that this principle, even if discovered by Hindu sages some three thousand years ago, is valuable and requires a secular universal foundation? We would perhaps call such a person a Hindu guru, but would hardly consider him a political philosopher. Yet, the situation is no different from that of liberal thinkers like Tuckness and others today.

The liberal thinkers too propagate Christian principles. This does not mean, however, they do so in an explicitly theological fashion, the way Locke and his contemporaries did. The ideas about the two spheres and liberty are not limited to Christian theological tracts; they have taken the form of attitudes towards the world. Cognitively speaking, these attitudes function as conditions of intelligibility for certain ideas, like, for example, the value of liberal toleration or the nature of human freedom.

The problems that the liberal theories of toleration face today are those that emerge from trying to provide secular universal foundations and arguments for the notion of Christian liberty and its two kingdoms. It is like trying to show in a "secular" language that the claims of Christianity are true. The attempt is about as plausible as explaining the notion of "the Christ" without bringing in the notions of Original Sin, God and His promise to mankind. In other words, the Judeo-Christian 
theology is the condition of intelligibility for the liberal theories of toleration. Where it is not available, these theories become radically unintelligible.

The consequences of this hypothesis come to light when liberal theories and institutions are extended to other cultures, which have not been shaped by Judeo-Christian religion. It has consequences within the West as well: this increasingly multicultural part of the world houses people, who are unrelated to the attitudes generated by the Judeo-Christian anthropology. How will such groups be accommodated in liberal nation-states, if the toleration model of these states reproduces and imposes a particular theological anthropology that lacks basic intelligibility to them?

Furthermore, the hypothesis downsizes the importance of research that presumes itself "secular" and "universal," while being deeply theological. Instead, it calls upon political theorists to look for other, more secular foundations for our societies by studying how cultures other than the West have tackled and solved the problem of pluralism. In short, if we desire to find new solutions to the growing pluralism of our multicultural societies, it is advisable to stop looking at the world through Christian glasses. 
Authors' Note: We would like to express our gratitude to Mary Dietz and two anonymous readers for helpful comments on an earlier draft of the essay.

1. Michael P. Zuckert, Launching Liberalism: On Lockean Political Philosophy (Lawrence, KA: University Press of Kansas, 2002), 1, 20.

2. Paul Bou-Habib, "Locke, Sincerity and the Rationality of Persecution," Political Studies 51(2003): 611-626, 623-5; Ingrid Creppell, “Locke on Toleration: The Transformation of Constraint,” Political Theory 24, no. 2(1996): 200-240, 231-2; Ruth W. Grant, John Locke's Liberalism (Chicago and London: The University of Chicago Press, 1987), 198-205; Alex Tuckness, "Rethinking the Intolerant Locke,” American Journal of Political Science 46, 2(2002): 288-298; Richard Vernon, The Career of Toleration: John Locke, Jonas Proast, and After (Montreal and Kingston: McGill-Queen’s University Press, 1997), 14-5; Anthony G. Wilhelm, “Good Fences and Good Neighbors: John Locke’s Positive Doctrine of Toleration," Political Research Quarterly 52, no. 1(1999): 145-166.

3. John Dunn, The Political Thought of John Locke: An Historical Account of the Argument of the 'Two Treatises of Government' (Cambridge: Cambridge University Press, 1969), xi.

4. John Marshall, John Locke: Resistance, Religion and Responsibility (Cambridge: Cambridge University Press, 1994), xviii. See also Richard Ashcraft, "Religion and Lockean Natural Rights," in Religious Diversity and Human Rights, eds. Irene Bloom, J. Paul Martin, and Wayne Proudfoot (New York: Columbia University Press, 1996), 208.

5. Jeremy Waldron, God, Locke, and Equality: Christian Foundations in Locke's Political Thought (Cambridge: Cambridge University Press, 2002), 82.

6. Ian Harris, The Mind of John Locke: A Study of Political Theory in Its Intellectual Setting (Cambridge: Cambridge University Press, 1994) and “The Politics of Christianity,” in Locke's Philosophy: Content and Context, ed. G. A. J. Rogers. Oxford: Clarendon Press, 1994); P. J. Kelly, “John 
Locke: Authority, Conscience and Religious Toleration," in John Locke: A Letter Concerning Toleration in Focus, ed. John Horton and Susan Mendus (London and New York: Routledge, 1991); Kim I. Parker, The Biblical Politics of John Locke (Waterloo, Ontario: Wilfred Laurier Press, 2004); Joshua Schwartzmann, “The Relevance of Locke's Religious Arguments for Toleration,” Political Theory 33(2005): 678-705.

7. Greg Forster, John Locke's Politics of Moral Consensus (Cambridge: Cambridge University Press, 2005), 21.

8. Waldron, God, Locke, and Equality, 242-243.

9. John Locke, "A Letter Concerning Toleration," Two Treatises of Government and a Letter Concerning Toleration, ed. Ian Shapiro (New Haven and London: Yale University Press, 2003), 218.

10. Ibid.

11. John Locke, "First Tract on Government," in Locke: Political Essays, ed. Mark Goldie. (Cambridge: Cambridge University Press, 1997), 11.

12. Bernard Williams, “Toleration: An Impossible Virtue?," in Toleration: An Elusive Virtue, ed. David Heyd (Princeton: Princeton University Press, 1996), 22.

13. Peter De Marneffe, "Liberalism, Liberty, and Neutrality," Philosophy and Public Affairs 19, no. 3(1990): 253-274, 255f.; Ronald Dworkin, A Matter of Principle (Cambridge, MA: Harvard University Press, 1985), 191-204; Charles Larmore, "Political Liberalism," Political Theory 18, no. 3(1990): 339360; John Rawls, Political Liberalism (New York: Columbia University Press, 1996). 14. Kirstie McClure, "Difference, Diversity and the Limits of Toleration," Political Theory 18, no. 3(1990): 361-391; Susan Mendus, Toleration and the Limits of Liberalism (Basingstoke: Macmillan, 1989), 9-11; Mary Warnock, “The Limits of Toleration," in On Toleration, eds. Susan Mendus and David Edwards (Oxford: Oxford University Press, 1987). 
15. Dworkin, A Matter of Principle, 335-72; David Dyzenhaus, "John Stuart Mill and the Harm of Pornography," Ethics 102(1992): 534-551; Bernard Harcourt, "The Collapse of the Harm Principle," Journal of Criminal Law \& Criminology 90, no. 1(1999): 109-195; Robert Skipper, "Mill and Pornography,” Ethics 103, no. 4(1993): 726-730. But see Richard Vernon, “John Stuart Mill and Pornography: Beyond the Harm Principle.” Ethics 106, no. 3(1996): 621-632.

16. Dworkin, A Matter of Principle, 336-7; John Gray, Mill on Liberty: A Defense (London: Routledge and Kegan Paul, 1983), 49.

17. Alan Wolfe, "Public and Private in Theory and Practice: Some Implications of an Uncertain Boundary," in Public and Private in Thought and Practice: Perspectives on a Grand Dichotomy, eds. Jeff Weintraub and Krishan Kumar (Chicago: The University of Chicago Press, 1997) 195.

18. E.g. Joe Bailey, "From Public to Private: The Development of the Concept of 'Private,"' Social Research 69, no. 1(2002): 15-32, 15; Jose Casanova, "Private and Public Religions," Social Research 59, no. 1(1992): 17-58, 17; Peter J. Steinberger, "Public and Private," Political Studies 47, no. 2(1999): 292313, 293; Jeff Weintraub, “The Theory and Politics of the Public/Private Distinction," in Public and Private in Thought and Practice: Perspectives on a Grand Dichotomy, eds. Jeff Weintraub and Krishan Kumar (Chicago: The University of Chicago Press, 1997), 2.

19. S. N. Balagangadhara, 'The Heathen in His Blindness...': Asia, the West, and the Dynamic of Religion (Leiden: Brill, 1994); Jakob De Roover, “The Vacuity of Secularism: On the Indian Debate and Its Western Origins,” Economic and Political Weekly 37, no. 39(2002): 4047-4053.

20. In the last section of the article, we will demonstrate the kind of difficulties that emerge in debates about liberal toleration in societies other than those of the West. The absence of a theoretical framework, which should allow one to identify at least one of the two spheres of liberal toleration, leads to endless disputes that cannot be settled on reasonable cognitive grounds. 21. Locke, “A Letter Concerning Toleration,” 241. 
22. Ibid.

23. Ibid., 242.

24. Ibid.

25. Ibid., 242-3.

26. John Locke, "Civil and Ecclesiastical Power," in Locke: Political Essays, ed. Mark Goldie (Cambridge: Cambridge University Press, 1997), 216.

27. John Locke, “An Essay on Toleration,” in Locke: Political Essays, ed. Mark Goldie (Cambridge: Cambridge University Press, 1997), A Second Letter Concerning Toleration (London, 1690) and A Third Letter for Toleration (London, 1692).

28. W. K. Jordan, The Development of Religious Toleration in England, 4 Vols. (Gloucester, MA: Peter Smith, 1965); John Coffey, Persecution and Toleration in Protestant England, 1588-1689 (Essex: Longman, 2000).

29. Martin Luther, "To the Christian Nobility of the German Nation," in Three Treatises (Minneapolis: Fortress Press, 1970).

30. See Martin Luther, “The Freedom of a Christian,” in Martin Luther's Basic Theological Writings, ed. Timothy F. Lull (Minneapolis: Fortress Press, 1989); Philip Melanchthon, “Loci Communes Theologici," in Melanchthon and Bucer, ed. Wilhelm Pauck (Philadelphia: The Westminster Press, 1969), 123.

31. John Calvin, Institutes of the Christian Religion, 2 vols., ed. John T. McNeill (Louisville: Westminster, 1960), vol. 2, 1180.

32. Calvin, Institutes, vol. 1, 847.

33. Martin Luther, "Temporal Authority: To What Extent It Should Be Obeyed," in Martin Luther's Basic Theological Writings, ed. Timothy F. Lull (Minneapolis: Fortress Press, 1989), 679.

34. Locke, Letter, 242. 
35. Richard H. Dees, "The Justification of Toleration," in Philosophy, Religion, and the Question of Intolerance, ed. Mehdi A. Razavi and David Ambuel (Albany, NY: State University of New York Press, 1997); John Dunn, “The Claim to Freedom of Conscience, Freedom of Speech, Freedom of Thought, Freedom of Worship?," in From Persecution to Toleration: The Glorious Revolution and Religion in England, ed. Ole P. Grell, Jonathan I. Israel, and Nicholas Tyacke (Oxford: Clarendon Press, 1991); Jeremy Waldron, "Locke: Toleration and the Rationality of Persecution," in Justifying Toleration: Conceptual and Historical Perspectives, ed. Susan Mendus (Cambridge: Cambridge University Press, 1988) and Waldron, God, Locke, and Equality.

36. Locke, "Letter," 220-226.

37. Ibid., 245.

38. Alex Tuckness, "Rethinking the Intolerant Locke," American Journal of Political Science 46, 2(2002): 288-298.

39. Ibid., 292; see Tuckness, Locke and the Legislative Point of View: Toleration, Contested Principles, and the Law (Princeton and Oxford: Princeton University Press, 2002).

40. Tuckness, "Rethinking the Intolerant Locke," 294.

41. Ibid., 295.

42. Ibid., 296-7.

43. "At level two there is the general principle that Locke derives from level one." Ibid., 295, italics supplied.

44. "God actually is a legislator and so must take into account the fallibility of all magistrates. If we are forced to reason from His perspective, we take into account the fallibility of others as well. This is important because we are often more accurate judges of the fallibility of others than of ourselves." (Ibid., 293; our emphasis.) How could human beings ever be forced to reason from God's 
perspective? One might 'know' that others are also fallible; but how could one ever take their fallibilities into account unless one is able to determine how, precisely, the others are fallible? 45. Ibid., 297, 298.

46. Consider another historical example. In the early days of colonial rule in India, the British officials confronted the practice of sati or "widow-burning." As the records show, they were willing to tolerate this practice (and they did tolerate it for several decades), if the native Hindu population could show that it was sanctioned by their religious scriptures. One of the justifications for tolerating this practice was eminently Lockean: even if the practice went against the biblical commandments and common morality, as fallible human beings the British officials were not allowed to infringe upon the consciences of others and what the latter took to be God's will. Consequently, the British allowed sati and other practices for the "Hindus," while forbidding them to subjects from other religions. This policy of toleration would have to end, in case it turned out that the Hindu scriptures did not sanction the practice. Consequently, it would have to be forbidden by law (as it was in 1829). Now, here is where the problem lies: both the toleration and the intolerance of sati become expressions of Lockean toleration, depending upon the presence or absence of an additional piece of knowledge. This demonstrates in historical terms what was said previously: whether or not some belief threatens the possibility of civil society does not depend on the nature of the belief (in itself), but on what we know or do not know about the world. Given the inevitable variation in background knowledge (spatially and temporally, but also individually), the specific principle becomes hollow: one and the same action is either Lockean toleration or not, depending upon the beliefs of the individual magistrate. Such a principle is completely inadequate as a foundation for toleration. 47. In his study of the influence of Locke's political thought on the American Revolution, Steven Dworetz shows how the common theological background of Christian liberty allowed the preachers of various Protestant confessions in the colonies to shape the American thought on religion and its 
liberty. Dworetz, The Unvarnished Doctrine: Locke, Liberalism, and the American Revolution (Durham, NC: Duke University Press, 1990), 137, 177.

48. Chris Beneke, Beyond Toleration: The Religious Origins of American Pluralism (New York: Oxford University Press, 2006).

49. Richard Perry, ed., Sources of Our Liberties: Documentary Origins of Individual Liberties in the United States Constitution and Bill of Rights (Chicago: American Bar Foundation, 1952), 312, 329, 349.

50. Susan Jacoby, Freethinkers: A History of American Secularism (New York: Henry Holt \& Co, 2004), 1-65; William G. McLoughlin, Soul Liberty: The Baptists' Struggle in New England, 1630-1833 (Hannover and London: Brown University Press, 1991), 249-69.

51. Jacoby, Freethinkers, 19.

52. Thomas Jefferson, Notes on the State of Virginia, ed. William Peden (Chapell Hill, NC: University of North Carolina Press, 1955), 223-5.

53. Jacoby, Freethinkers, 24.

54. Thomas Jefferson, The Writings of Thomas Jefferson, Vol. 16, ed. Albert E. Bergh, Richard H. Johnson, and Andrew A. Lipscomb (Washington DC: Thomas Jefferson Memorial Association of the United States, 1903), 281-2.

55. Derek H. Davis, “Thomas Jefferson and the 'Wall of Separation' Metaphor," Journal of Church and State 45, no. 1(2003): 5-14, 7-8; see also Edwin S. Gaustad, “Thomas Jefferson, Religious Freedom, and the Supreme Court," Church History 67(1998): 682-694.

56. Jefferson, Notes on the State of Virginia, 159.

57. Ibid., 159-161.

58. Robert K. Faulkner, "Political Philosophy," in Encyclopedia of the Enlightenment, Vol. 3, ed. Alan Charles Kors (Oxford: Oxford University Press, 2003), 320. 
59. See especially the debates of the Constituent Assembly of the 1940s, which preceded the creation of the Indian Constitution. Constituent Assembly Debates, Official Report, third reprint (New Delhi: Lok Sabha Secretariat, 1999), vol. 7, 721-2, 756-9, 817-9. See also the analyses in Rochana Bajpai, "The Conceptual Vocabulary of Secularism and Minority Rights in India," Journal of Political Ideologies 7, no. 2(2002): 179-197 and De Roover, "Vacuity of Secularism." These show how the same debates are still continuing in contemporary India. No solution is in sight.

60. E.g. Ruma Pal, "Religious Minorities and the Law," in Religion and Personal Law in Secular India: A Call to Judgment, ed. Gerald J. Larson (Bloomington and Indianapolis: Indiana University Press, 2001). See also Constituent Assembly Debates, vol. 7, 781-782.

61 In India, the secular state appears to have imposed one such conception of religion on society. See S. N. Balagangadhara and Jakob De Roover, "The Secular State and Religious Conflict: Liberal Neutrality and the Indian Case of Pluralism,” Journal of Political Philosophy 15, no. 1(2007): 67-92. 62. See: Jakob De Roover and S. N. Balagangadhara, "Liberty, Tyranny and the Will of God: The Principle of Toleration in Early Modern Europe and Colonial India," Forthcoming; Jonathan I. Israel, Locke, Spinoza and the Philosophical Debate Concerning Toleration in the Early Enlightenment (c. 1670 c.1750) (Amsterdam: Koninklijke Nederlandse Academie van de Wetenschappen, 1999). 63. As Gordon Schochet puts it: "The guiding presumptions—-widely shared in the West—are that religion is generally a matter of personal conscience and that religious practices that do not threaten the stability or security of the state ought not to be interfered with." Schochet, "Toleration," in Encyclopedia of the Enlightenment, ed. Alan Charles Kors (Oxford: Oxford University Press, 2003), 165. E.g. Robert Audi, “The Separation of Church and State and the Obligations of Citizenship." Philosophy \& Public Affairs 18, no. 3(1989): 259-296. 
Jakob De Roover is a Postdoctoral Fellow of the Research Foundation (FWO) Flanders at the Research Centre Vergelijkende Cultuurwetenschap, Ghent University, Belgium.

S. N. Balagangadhara is Professor and Director, Research Centre Vergelijkende Cultuurwetenschap, Ghent University, Belgium. 